\title{
Non-synonymous FBXW7 Gene Mutation
}

National Cancer Institute

\section{Source}

National Cancer Institute. Non-synonymous FBXW7 Gene Mutation. NCI Thesaurus.

Code C158678.

A point mutation in the FBXW7 gene that encodes an amino acid substitution in the Fbox/WD repeat-containing protein 7 protein. 